\title{
PENGARUH EMPATI TERHADAP PEMAAFAN DAN PERCAYA DIRI DALAM HUBUNGAN PERTEMANAN
}

\author{
Nadya Alawwiyah \\ Fakultas Kedokteran Universitas Lambung Mangkurat \\ Email: nadyaalawwiyah@gmail.com
}

\begin{abstract}
ABSTRAK
Di dalam hubungan pertemanan seseorang kerap kali melakukan kesalahan dalam melakukan sesuatu hal yang mengakibatkan terjadinya konflik dalam relasi sosial, sehingga memaafkan adalah suatu hal yang paling baik dan benar yang dilakukan untuk membentuk suatu pertemanan menjadi hubungan yang berkualitas. Tetapi tetap saja, pemaafan akan sangat sulit dilakukan oleh orang-orang yang kurang memiliki rasa empati terhadap sesamanya. Tujuan penelitian ini adalah untuk mengetahui pengaruh empati terhadap pemaafan dan saling mendukung untuk percaya diri dalam hubungan pertemanan. Metode penelitian ini adalah penelitian kuantitatif, Penelitian ini menggunakan dua jenis skala yaitu skala empati dan skala pemaafan. Hasil dari penelitian ini menunjukkan bahwa rasa empati yang dimiliki oleh seseorang sangat berpengaruh terhadap pemaafan dan percaya diri dalam hubungan pertemanan, karena dengan adanya rasa empati, seseorang memiliki kepedulian yang tinggi terhadap orang lain, mampu memahami perasaan orang lain, bisa merasakan apa yang dirasakan orang lain, bisa menjadi pendengar yang baik, bahkan menumbuhkan kepercayaan diri seorang teman dan banyak lagi hal-hal posotif lainnya. Implikasi dari hasil penelitian ini dibahas pada konteks hubungan interpersonal.
\end{abstract}

Kata Kunci: Empati, Pemaafan, Hubunngan Pertemanan. 


\section{Pendahuluan}

Sebagian besar individu pernah merasa tersakiti dan memerlukan cara untuk mengatasi luka tersebut. Untuk mengatasi luka hati, salah satunya adalah dengan cara memaafkan. Memaafkan adalah salah satu cara untuk melepaskan kekesalan, dendam, emosi negatif yang muncul akibat perlakuan menyakitkan yang dilakukan oleh seseorang terhadap diri kita. Semakin besar luka yang ditimbulkan, maka akan semakin sulit untuk memaafkan, semakin besar rasa sakit hati dan semakin lama pula waktu yang diperlukan untuk kita bisa memaafkan orang tersebut apalagi orang tersebut teman dekat kita sendiri. Jadi, jika kita mampu memaafkan orang lain dengan ikhlas dan lapang dada, maka pemberian maaf kita kepada orang yang menyakiti kita akan menggantikan rasa sakit dengan rasa damai (Post dan Neimark, 2011).

Salah satu argumen yang paling sering dikemukakan dan paling salah terhadap memaafkan adalah jika memaafkan berarti menunjukkan bahwa orang yang melakukan kesalahan tersebut bisa berlaku sesuka hati, tetapi memaafkan bukanlah tentang memberikan kekuasaan. Jika dapat memaafkan dengan sangat baik, individu harus menggali lebih dalam dan hal ini membutuhkan keberanian serta empati.

Memaafkan bukanlah tindakan yang mudah. Memaafkan membutuhkan sebuah perjuangan dan proses. McCullough dkk. (1997) menyatakan bahwa memaafkan merupakan upaya untuk membawa perasaan negatif dan menggantinya dengan pikiran, perasaan, dan tindakan yang positif. Pada kenyataannya, memaafkan tidak mudah dilakukan apalagi secara cepat. Selalu ada persoalan psikologis di antara dua belah pihak yan pernah mengalami keretakan hubungan akibat suatu kesalahan. Permintaan maaf memiliki kemampuan untuk menghapuskan kebencian dan kepahitan, dalam hal ini yaitu kebencian dan kepahitan yang dirasakan bagi orang yang tersakiti. Memaafkan efektif mengembalikan hubungan sosial yang rusak antara individu tersebut dengan orang yang menyakitinya (McCullough dkk., 2006).

Bullying juga dapat membuat kita tidak percaya diri. Namun ketika kita telah berempati dan memaafkan orang - orang yang membully maka akan hilang perasaan negatif dan menumbuhkan perasaan yang positif seperti percaya diri (Rachmah, D. N., 2016).

\section{Pemaafan}

Menurut Michael McCullough, salah seorang pakar dalam psychology of forgiveness, pemaafan adalah berkurangnya keinginan untuk menghindari orang yang pernah menyakiti kita, dan berkurangnya keinginan untuk melukai atau membalas dendam kearah individu tersebut dan disertai meningkatnya belas kasih (compassion) dan keinginan untuk bertindak secara positif ke arah orang yang menyakiti (Arif, 2016:95). McCullough dkk mengemukakan bahwa pemaafan merupakan seperangkat motivasi untuk mengubah seseorang untuk tidak membalas dendam dan meredakan dorongan untuk memelihara kebencian terhadap pihak yang menyakiti serta meningkatkan dorongan untuk konsiliasi hubungan dengan pihak 
yang menyakiti (McCullough \& Worthington dkk, 1997). Enright mendefinisikan memaafkan sebagai sikap untuk mengatasi hal-hal yang negatif dan penghakiman terhadap orang yang bersalah dengan tidak menyangkal rasa sakit itu sendiri tetapi dengan rasa kasihan, iba dan cinta kepada pihak yang menyakiti dalam (Silfiasari \& Prasetyaningrum, 2017). Nashori (2012) pemaafan diartikan sebagai kesediaan untuk meninggalkan hal-hal yang tidak menyenangkan yang bersumber dari hubungan interpersonal dengan orang lain dan menumbuh kembangkan pikiran, perasaan, dan hubungan interpersonal yang positif dengan orang lain yang melakukan pelanggaran secara tidak adil. Menurut Hughes memaafkan merupakan cara untuk memperbaiki harmoni sosial. Untuk sebagian orang memaafkan adalah suatu kebutuhan karena dapat memperbaiki hubungan dengan orang lain (Girarld \& Mullet, 1997). Beberapa penelitian Darby \& Schlenker (1982) menemukan bahwa meminta maaf sangat efektif dalam mengatasi konflik interpersonal karena permintaan maaf merupakan sebuah pernyataan tanggung jawab tidak bersyarat atas kesalahan dan sebuah komitmen untuk memperbaikinya (Paramitasari \& Alfian, 2012). Pemaafan berkaitan dengan peningkatan kebahagiaan, keramahan, harapan dan kemampuan untuk membangun kembali kedekatan dalam hubungan (Lyubomirsky, 2007; Neto dan Mullet, 2004).

\section{Empati}

Ada banyak hal yang mempengaruhi seseorang dalam proses pemaafan, salah satunya adalah empati. Davis (1980) mengatakan empati adalah kemampuan seseorang untuk mengenal dan memahami emosi, pikiran serta sikap orang lain. Empati termasuk dalam kemampuan untuk merasakan keadaan emosional orang lain, merasa simpati dan mencoba menyelesaikan masalah, serta mengambil perspektif orang lain. Cakupan-cakupan pokok empati berkisar pada sudut objek orang lain, yang menciptakan keinginan untuk menolong, mengalami emosi yang serupa dengan emosi orang lain, mengetahui apa yang di rasakan dan pikirkan, serta mengaburkan batasan antara diri sendiri dan orang lain. Smith (2006) mengatakan bahwa empati berperan utama dalam pembentukan perilaku manusia. Empati pada umumnya didefenisikan sebagai proses respon emosional seseorang terhadap pengalamannya juga proses mengerti dan memahami dari perspektif orang lain mengenai emosi yang terjadi dan rasakan (Sağkal, 2012).

Hopkins, Barr, Michel dan Rochat (2005) mendefinisikan empati sebagai keadaan merasakan perasaan negatif atau menyakitkan dari orang lain. Empati membuat seseorang sensitif terhadap emosi orang lain meski situasinya sendiri berbeda. Empati muncul pada usia dua atau tiga tahun, dan emosi ini tidak memiliki ekspresi wajah yang unik seperti emosi lain. Eisenberg, Batson, Davis, Fesbach, Hoffman (dalam Taufik, 2012) menyatakan bahwa empati terdiri atas dua komponen, kognitif dan afektif. Selain kedua komponen tersebut beberapa teoritikus lainnya menambahkan aspek komunikatif sebagai faktor ketiga. Goleman (2011) menyatakan empati dibangun berdasarkan kesadaran diri. Semakin terbuka kita kepada emosi diri sendiri, semakin terampil kita membaca perasaan. Kemampuan berempati yaitu kemampuan untuk mengetahui bagaimana perasaan orang lain. Emosi jarang diungkapkan dengan kata-kata, emosi jauh lebih sering 
diungkapkan melalui isyarat. Kunci untuk memahami perasaan orang lain adalah mampu membaca pesan nonverbal: nada bicara, gerak-gerik, ekspresi wajah, dan sebagainya.

Goleman (2011) berpendapat bahwa akar empati itu sudah ada pada seseorang sejak mereka masih bayi atau sejak mereka lahir. Tanda-tanda awal empati ini dicontohkan sebagaimana bayi akan menangis ketika bayi mendengar bayi lain menangis. Seorang anak umur satu tahun akan mengulum jarinya sendiri untuk mengetahui apakah ia juga terluka, ketika melihat bayi lain terluka jarinya. Anak akan menghapus matanya meskipun ia tak menangis, ketika melihat ibunya menangis.

Keen (dalam Tarwilah, 2009) mengatakan bahwa empati adalah mengenali perasaan orang lain dan memahami pengalaman emosional orang lain tanpa berpartisipasi didalamnya. Empati adalah sebuah sikap bagaimana individu memahami perasaan orang lain tanpa mengalaminya sendiri. Empati yaitu suatu kemampuan untuk memahami, mengerti, tentang perasaan dan emosi orang lain serta mampu membayangkan diri sendiri jika berada di posisi orang lain. Selain itu pula empati merupakan kemampuan untuk menempatkan diri sendiri dalam keadaan psikologis orang lain dan untuk melihat suatu situasi dari sudut pandang orang lain. Empati juga dapat dipahami sebagai kemampuan "menyelaraskan diri” (peka) terhadap apa, bagaimana dan latar belakang perasaan dan pikiran orang lain sebagaimana orang tersebut merasakan dan memikirkannya.

Ketika individu akan memberikan maaf, individu tersebut pasti mengingat kembali rasa sakit yang diterima dari orang yang menyakiti dan membutuhkan empati yang baik (McCullough, 2000). Perasaan positif seperti empati akan memberikan kontribusi pada perkembangan moral orang lain khususnya remaja. Ketika individu memaafkan seseorang yang telah melukainya terjadi penurunan motivasi untuk menghindari dan menyakiti orang tersebut (Mc Cullough, 2000).

Dalam berinteraksi dengan orang lain seseorang kadang-kadang berbuat salah kepada orang lain. Begitu juga yang terjadi pada mahasiswa. Mahasiswa dalam menjalin hubungan dengan orang lain baik dengan teman sebayanya ataupun dengan orang yang berada disekitarnya tidak menutup kemungkinan akan terjadi konflik. Mahasiswa tentu pernah mengalami perlakuan dan situasi yang mengecewakan atau menyakitkan. Hal inilah yang membuat hubungan mahasiswa dengan orang disekililingnya menjadi bermasalah, sehingga membutuhkan sikap untuk memaafkan. Ketika seseorang tidak bisa untuk memaafkan, ia akan memperoleh berbagai kerugian diantaranya yaitu hati dipenuhi emosi negatif seperti dendam, marah dan benci terhadap orang yang telah menyakitinya. Rasa marah, benci dan dendam juga berpengaruh terhadap psikologis. Ahli- ahli psikologi sosial menjelaskan bahwa perilaku agresif terjadi akibat rasa benci dan rasa dendam yang dimiliki seseorang (Nashori, 2008). Selain itu, tidak 
memaafkan berkorelasi positif dengan depresi, kecemasan, permusuhan dan neurotisisme.

\section{Kajian Literatur}

Kajian literatur merupakan kegiatan yang dilakukan untuk mempelajari penemuan-penemuan terdahulu yang pada dasarnya adalah untuk mendapatkan gambaran hubungan topik yang diteliti dengan hasil penelitian sebelumnya.

Penelitian dalam jurnal yang ditulis oleh Silvia sari, mahasiswi dari fakultas psikologi, Universitas Muhammadiyah, Malang, "Empati dan Pemaafan dalam Hubungan Pertemanan Siswa Reguler Kepada Siswa Berkebutuhan Khusus (ABK) di Sekolah Inklusif' pada tahun 2017. Hasil penelitiannya menunjukkan bahwa, Hasil penelitian menunjukkan bahwa ada hubungan yang positif antara empati dan pemaafan dalam hubungan pertemanan siswa biasa kepada siswa ABK di sekolah inklusif. ( $\mathrm{r}=0,323 ; \mathrm{p}=0,001 ; \mathrm{p}<0,005)$.

Selanjutnya jurnal yang ditulis oleh Dewi Anggraini dan Hijriyati cucuani, mahasiswi dari Fakultas Psikologi UIN Sultan Syarif Kasim, Riau, "Hubungan Kualitas Persahabatan dan Empati pada Pemaafan Remaja Akhir" pada tahun 2014. Hasil penelitiannya menunjukkan bahwa kualitas persahabatan dan empati memiliki hubungan yang signifikan dengan pemaafan pada remaja akhir. Dengan demikian, dapat ditarik kesimpulan bahwa kualitas persahabatan dan empati mempermudah remaja akhir dalam memaafkan orang lain.

Selanjutnya yaitu Tesis yang di tulis oleh Riska Fitriani, mahasiswi dari Fakultas Psikologi UIN Sultan Syarif Kasim, Riau "Hubungan Antara Empati dan Komitmen dengan Pemaafan Dalam Persahabatan Remaja (Studi Pada Remaja di SMPN 3 Seberida, Kab. Indragiri Hulu)" pada tahun 2020. Hasil Penelitiannya menunjukkan bahwa secara parsial ada hubungan signifikan antara empati terhadap pemaafan, dan terdapat hubungan yang signifikan juga antara komitmen terhadap pemaafan. Secara simultan terdapat hubungan yang signifikan antara empati dan komitmen terhadap pemaafan. Hasil penelitian ini juga menunjukan bahwa empati dan komitmen memberikan sumbangan efektif sebesar 23,7\% terhadap pemaafan dan sisanya sebesar $76,3 \%$ dari faktor lain yang tidak diteliti dalam penelitian ini.

Selanjutnya jurnal yang di tulis oleh Dwi Nur Rachmah, mahasiswa Universitas Lambung Mangkurat, Banjarbaru, Kalimantan Selatan, "Empati Pada Pelaku Bullying" pada tahun 2014. Hasil penelitiannya menunjukkan bahwa alasan pelaku bullying melakukan perbuatan bullying yaitu dikarenakan faktor karakteristik korban, sikap korban, tradisi/budaya bullying di sekolah. Pelaku bullying melakukan bullying juga dikarenakan memiliki kemampuan empati yang rendah. Ketidakmampuan pelaku untuk berempati menyebabkan mereka kurang mampu untuk melihat dari sudut pandang orang lain, mengenali perasaan orang lain dan menyesuaikan kepeduliannya dengan tepat. Kurangnya empati dari pelaku menyebabkan pelaku kurang memahami kondisi korban, tidak peduli dengan korban dan cenderung melakukan tindakan kekerasan kepada orang atau korban.

\section{Hasil dan Pembahasan}


Berdasarkan hasil penelitian yang dilakukan terhadap pengaruh empati terhadap pemaafan dalam hubungan pertemanan mahasiswa, maka dapat dibahas sebagai berikut:

\section{Pengukuran}

Pengukuran dalam penelitian ini menggunakan dua alat ukur dengan jenis skala model Likert, yaitu empati dan pemaafan.

1. Skala Empati

Variabel empati dalam penelitian ini diukur dengan Interpersonal Reactivity Index (IRI) dari Davis. Peneliti juga menambahkan beberapa item yang mempunyai maksud sama untuk mengukur empati sehingga berjumlah 36 item. Skala Interpersonal Reactivity Index (IRI) terbagi dalam empat subskala. Keempat subskala tersebut yaitu Perspektive-Taking (PT) terdiri atas item-item yang mengukur kecenderungan untuk memahami pandangan-pandangan orang lain, Emphatic Concern (EC) untuk mengukur kecenderungan terhadap pengalaman-pengalaman yang berhubungan dengan "kehangatan", "rasa iba", dan perhatian terhadap kemalangan oranglain, Personal Distress (PD) mengukur kecemasan pribadi yang berorientasi pada diri sendiri serta kegelisahan dalam mengahadapi setting interpersonal yang tidak menyenangkan dan Fantasy (FS) cenderung untuk menempatkan diri sendiri ke dalam perasaan dan perilakuperilaku dari karakter-karakter yang ada di dalam buku cerita, novel, film, dan lain sebagainya. Rentang penilaian, $1=$ sangat tidak sesuai sampai $5=$ sangat sesuai. Contoh "Saya merasakan sedih ketika melihat orang lain terluka." Setelah dilakukan try out, 10 item yang gugur dengan reliabilitas 0,932 .

\section{Skala Pemaafan.}

Variabel pemaafan dalam penelitian ini diukur dengan menggunakan Transgression-Related Interpersonal Motivations (TRIM-18). TransgressionRelated Interpersonal Motivations (TRIM-18) adalah skala yang dikembangkan oleh Michael E. McCullough. Peneliti juga menambahkan beberapa item yang mempunyai maksud sama untuk mengukur pemaafan sehingga berjumlah 30 item. Menurut McCullough (2000), aspek pemaafan terdiri dari tiga unsur, yaitu: avoidance motivations, yaitu motivasi penghindaran terhadap orang yang telah menyakiti, revenge motivations, yaitu motivasi untuk membalas dendam, dan benevolence motivations, yaitu motivasi melakukan kebaikan dan berdamai dengan pelaku. Rentang penilaian, $1=$ sangat tidak sesuai sampai $5=$ sangat sesuai, contoh item "Saya tetap ingin menjaga hubungan baik dengan orang yang telah menyakiti saya." Setelah dilakukan try out, 3 item yang gugur dengan reliabilitas 0,918 .

\section{Uji Normalitas dan Linearitas}

Berdasarkan uji normalitas diperoleh rasio skewness untuk variabel empati (X) sebesar $-4,230$ dan rasio kurtosis sebesar 5,97. Sedangkan untuk variabel pemaafan ( $\mathrm{Y}$ ) diperoleh rasio skewness sebesar -2,546 dan rasio kurtosis sebesar 0,090. Maka dapat disimpulkan bahwa sebaran pada variabel empati tidak normal 
sedangkan variabel pemaafan normal. Berdasarkan hasil uji linearitas yang telah dilakukan diperoleh F sebesar 32.902 dengan taraf signifikansi 0,000, sehingga dapat disimpulkan bahwa kedua variabel linear. Hasil uji linear dalam penelitian ini diketahui bahwa arah hubungan kedua variable positif.

\section{Uji Hipotesis}

Untuk menguji hipotesis yang diajukan diterima atau ditolak, maka dilakukan analisis data. Oleh karena asumsi normalitas tidak terpenuhi, maka teknik statistik yang digunakan adalah teknik nonparametrik, yaitu korelasi Rank Spearman dengan bantuan program komputerisasi SPSS 16.0 for windows. Berdasarkan hasil analisis teknik korelasi Rank Spearman diperoleh koefisien antara empati dengan pemaafan sebesar 0,316 pada taraf signifikansi 0,000 (Lampiran J). Hipotesis dikatakan signifikan jika memiliki taraf signifikan kurang dari $1 \%$ (p < $0,01)$ atau kurang dari 5\% ( $\mathrm{c}<0,05)$. Dengan demikian dapat dikatakan bahwa antara empati dengan pemaafan terdapat hubungan yang signifikan. Jadi hipotesis yang diajukan dalam penelitian ini diterima, yaitu terdapat hubungan positif antara empati dengan pemaafan pada mahasiswa.

Dari hasil penelitian menunjukkan bahwa hipotesis diterima, yaitu terdapat hubungan positif antara empati dengan pemaafan dalam hubungan pertemanan mahasiswa. Uji hipotesis dengan menggunakan teknik korelasi Rank Spearman dengan bantuan spss 16.0 for windows diperoleh koefisien korelasi sebesar 0,316 dengan taraf signifikansi 0,000. Dengan demikian dapat dikatakan bahwa antara empati dengan pemaafan terdapat hubungan yang positif. Artinya semakin tinggi empati mahasiswa maka semakin tinggi pula pemaafannya. Begitu juga sebaliknya, semakin rendah empati mahasiswa maka semakin rendah juga pemaafannya.

Hal yang senada juga disampaikan oleh McCullough (2000) yang mengatakan bahwa empati akan mempengaruhi atau memotivasi seseorang untuk memberikan maaf terhadap orang lain. Artinya, semakin baik seseorang memiliki rasa untuk berempati, maka akan semakin baik pula dalam memberikan pemaafan terhadap orang yang menyakitinya. Jika mahasiswa mampu menempatkan diri pada sudut pandang orang yang telah menyakiti, maka mahasiswa akan mampu memahami motivasi dan alasan kenapa orang yang telah menyakiti melakukan hal tersebut. Hasil penelitian ini diperkuat oleh McCullough dkk (1997) yang menyatakan bahwa empati merupakan elemen yang sangat penting dalam pemaafan karena melalui empati, individu mampu memaafkan dan menumbuhkan perasaan positif terhadap orang yang telah menyakiti.

Berdasarkan hasil uji korelasi setiap aspek empati dengan pemaafan diketahui bahwa aspek perspective taking, emphatic concern dan personal distress mempunyai hubungan yang sangat signifikan dengan pemaafan. Hal ini dikarenakan ketika individu akan memberikan maaf, individu tersebut pasti mengingat kembali rasa sakit yang diterima dari orang yang menyakiti. Hal ini melibatkan perspective taking. Perspective taking berkaitan dengan theory of mind. Menurut theory of mind kunci pokok dari perspective taking terletak pada kemampuan seseorang dalam mengoptimalkan pikirannya untuk memahami kondisi orang lain, melalui pemaknaan sikap dan perilaku yang dilihatnya (Taufik, 2012). Melalui kemampuan pemahaman dan pengambilan sudut pandang (perspective 
taking) dari orang yang menyakiti, individu bisa menempatkan dirinya pada orang yang telah menyakitinya dan mengetahui motivasi apa yang bisa menyebabkan pelaku melakukan hal tersebut hingga akhirnya individu memutuskan untuk dapat memaafkan.

Emphatic concern termasuk dalam komponen afektif dalam empati (Taufik, 2012). Secara afektif, orang yang berempati merasakan apa yang orang lain rasakan. Empati secara afektif merujuk pada kemampuan menselaraskan pengalaman emosional pada orang lain, yang terdiri atas simpati, sensitivitas, dan sharing penderitaan yang dialami orang lain seperti perasaan dekat terhadap kesulitankesulitan orang lain yang diimajinasikan seakan-akan dialami oleh diri sendiri (Colley, dalam Taufik 2012). Apabila individu mampu membayangkan jika dirinya sendiri berada disituasi yang pernah melakukan kesalahan terhadap orang lain dan membutuhkan pemaafan maka individu tersebut pasti mampu memaafkan kesalahan orang yang telah menyakitinya. Hal ini dikarenakan individu mampu merasakan apa yang dibutuhkan oleh seorang yang telah melakukan kesalahan, yaitu kebutuhan untuk dimaafkan.

Sama halnya dengan aspek emphatic concern, aspek personal distresss juga termasuk kedalam komponen afektif dalam empati. Personal distres berarti kecemasan pribadi yang berorientasi pada diri sendiri serta kegelisahan dalam mengahadapi setting interpersonal yang tidak menyenangkan (Davis, 1983). Setting interpersonal yang tidak menyenangkan disini diartikan yaitu ketika mahasiswa mengalami konflik dengan orang lain merasa berada pada situasi yang tidak menyenangkan, cemas dan merasa gelisah. Sehingga hal ini membuat individu yang merasa tersakiti akan memaafkan orang yang telah menyakitinya untuk mendapatkan ketenangan hati. Hal ini telah dibuktikan secara empiris dalam penelitian eksperimen yang dilakukan Frederic Luskin (dalam Taufik, 2012) yang menunjukkan adanya efek memaafkan secara total terhadap kesehatan emosional. Mahasiswa yang dilatih memaafkan ternyata jauh lebih tenang kehidupan sosialnya. Mahasiswa menjadi tidak mudah marah, tidak mudah tersinggung dan dapat membina hubungan lebih baik dengan sesama (Nashori, 2008).

Berdasarkan pernyataan tersebut, maka dapat disimpulkan bahwa empati memang merupakan aspek yang penting dalam pemberian maaf.

\section{Kesimpulan}

Dari penjelasan di atas dapat disimpulkan bahwa terdapat hubungan positif signifikan antara empati dan pemaafan. Dengan demikian, semakin tinggi empati maka semakin tinggi pula pemaafannya. Empati akan mempengaruhi atau memotivasi seseorang untuk memberikan maaf terhadap orang lain. Artinya, semakin baik seseorang memiliki rasa untuk berempati, maka akan semakin baik pula dalam memberikan pemaafan terhadap orang yang menyakitinya. Jika seseorang mampu menempatkan dirinya pada sudut pandang pihak yang menyakiti, maka seseorang tersebut akan dapat memahami motivasi dan alasan kenapa orang yang menyakiti melakukan hal tersebut. Empati juga merupakan elemen yang sangat penting dalam pemaafan karena, melalui empati individu mampu memaafkan dan menumbuhkan perasaan positif terhadap orang yang menyakitinya. 


\section{DAFTAR PUSTAKA}

Davis, M. H., A Multidimensional Approach to Individual Differences In Empathy.JSAS Catalog of Selected Documents in Psychology, 1980.

Davis, Mark H. Measuring Individual Differences in Emphaty: Evidence for a Multidimensional Approach. Journal of Personality and Social Psychology. Vol. 44. No. 1, 1983.

Goleman, D. Emotional Mastery. Leadership Excellence. 2011 Diunduh Pada tanggal 2 Desember 2020.

Hafifah, D. N., Febriana, S. K. T., \& Fauzia, R., Efektivitas pendampingan psikologi dengan metode Appreciative Inquiry Untuk meningkatkan kepercayaan diri. Jurnal Ecopsy, 2016.

Hopkins, B., Barr, R. G., Michel, G. F., \& Rochat, P. The Cambridge Encyclopedia Of Child Development. Cambridge: Cambridge University Press, 2005.

Mayara, B. H., Yuniarrahmah, E., \& Mayangsari,M.D. Hubungan Kepercayaan Diri dengan Konformitas Pada Remaja. Jurnal Ecopsy, 2017.

McCullough, Michael E., Worthington, Everentt L., Rachal, Kenneth. Interpersonal Forgiving in Close Relationships. Journal of Personality and Social Psychology, 1997.

McCullouhg, M. E. Forgiveness As Human Strength: Theory, Measurement, and Links To Well-Being, Journal of Social and Clinical Psychology, 2000.

McCullough, M E., Root, Lindsey M., Cohen, Adam D, Writing About the Benefits of an Interpersonal Transgression Facilitates Forgiveness. Journal of Consulting and Clinical Psychology, 2006.

Nashori, F. Psikologi Sosial Islam, Bandung: PT. Refika Aditama, 2008.

Post, S \& , Neimark, J. Why Good Things Happen to Good People. Bandung: PT. Mizan Pustaka, 2011.

Putri, L. A., Anward, H. H., \& Zwagery, R. V. Perbedaan Kualitas Persahabatan Ditinjau Dari Gaya Kelekatan Pada Mahasiswa Psikologi Fakultas Kedokteran Ulm. Kognisia prodi Psikologi FK ULM, 2020.

Rachmah, D. N., Empati pada pelaku bullying. Jurnal Ecopsy, 2016.

Ramadhani, H. R., Anward, H. H., \&Rachmah, D. N. Peranan Lima Besar Kepribadian terhadap Kecenderungan Buli pada Remaja. Jurnal Ecopsy, 2016. 
Rohimah, S., Mayangsari, M. D., \& Fauzia, R. Hubungan Regulasi Diri dalam Belajar dengan Perfeksionisme pada Siswa SMA Boarding School. Jurnal Ecopsy, 2016.

Safitri, J., \& Mayangsari, M. D., Efektivitas Metode Sosiodrama Terhadap Keterampilan Sosial Pada Siswi Smp Pondok Pesantren An-Najah Martapura. Kognisia prodi Psikologi FK ULM, 2020.

Sagkal, A.S, Abbas T, \& Tarı T. Empathy For Interpersonal Peace: Effects Of Peace Education On Empathy Skills. Educational ciences: Theory \& Practice-12(2) Supplementary Special Issue, 2012.

Smith, A. Cognitive Empathy and Emotional Empathy In Human Behavior And Evolution. The Psychological Record, 2006.

Tarwilah., Metode Pembelajaran Pada Anak Prasekolah Dalam Ittihad Jurnal Kopertis W Wilayah Xi Kalimantan, 2009, Volume 7 No.12 Oktober.

Taufik. Empati Pendekatan Psikologi Sosial, Jakarta: Raja Grafindo Persada, 2012. 